\title{
FAKTOR DOMINAN RISIKO TERJADINYA PENYAKIT JANTUNG KORONER (PJK)
}

\author{
Ros Endah Happy Patriyani, David Ferry Purwanto \\ Kementerian Kesehatan Politeknik Kesehatan Surakarta Jurusan Keperawatan,RSUP dr. Karyadi \\ Semarang
}

\begin{abstract}
Risk Factors, CHD. Coronary Heart Disease (CHD) is the coronary atherosclerotic disease that causes narrowing of blood vessels. Constriction of blood vessels occurs because of atherosclerosis or spasm or a combination of both. the risk factors of CHD were divided into two, namely the factors that can not be changed and the factors can be changed. Factors that can not be changed include age, family history and gender. While the factors that can be changed include an increase in serum lipids (hyperlipidemia), personality type, smoking, impaired glucose tolerance (diabetes mellitus), lifestyle is less activity (physical inactivity), psychological stress, and hypertension. The purpose of this study to determine the risk factors that lead to increased incidence of coronary heart disease. The study is an observational analytic epidemiologic approach with cross sectional design with a sample of 40 respondents. The data analysis using logistic regression. The results showed the significant influence of CHD events by a factor of age $>40$ years $(p=0.7370$, hyperlipidemia $(p=0162)$, hypertension ( $p=0365)$, smoking $(p=0153)$, as well as physical inactivity $(p=0535)$. Smoking is a risk factor most dominant effect on the incidence of CHD with OR= 4,500. the case studies are necessary to further research with a number of larger samples and develop variable-varabel to be studied is associated with other behaviors and lifestyles that affect developing CHD.
\end{abstract}

\section{Key words: Risk Factors, CHD}

\begin{abstract}
Abstrak: Faktor Risiko, PJK. Penyakit Jantung Koroner (PJK) adalah penyakit aterosklerotik koroner yang menyebabkan penyempitan pembuluh darah. Penyempitan pembuluh darah terjadi karena proses aterosklerosis atau spasme atau kombinasi keduanya. faktor risiko terjadinya PJK dibagi menjadi dua, yaitu faktor yang tidak dapat diubah dan faktor dapat diubah. Faktor yang tidak dapat diubah meliputi usia, riwayat keluarga, dan jenis kelamin. Sedangkan faktor yang dapat diubah meliputi peningkatan lipid serum (hiperlipidemia), tipe kepribadian, merokok, gangguan toleransi glukosa (diabetes melitus), gaya hidup kurang aktivitas (inaktivitas fisik), stress psikologis, dan hipertensi. Tujuan dari penelitian ini untuk mengetahui faktor risiko yang menyebabkan meningkatnya angka kejadian penyakit jantung koroner. Penelitian yang bersifat observasional analitis pendekatan epidemologis dengan desain penelitian cross sectional dengan jumlah sampel 40 responden. Analisis data menggunakan regresi logistik. Hasil penelitian menunjukkan adanya pengaruh yang signifikan antara kejadian PJK dengan faktor umur $>40$ tahun $(\mathrm{p}=0.7370$, hiperlipidemia ( $\mathrm{p}=0.162)$, hipertensi $(\mathrm{p}=0.365)$, kebiasaan merokok $(\mathrm{p}=0.153)$, serta inaktivitas fisik $(\mathrm{p}=0.535)$. Merokok merupakan faktor risiko paling
\end{abstract}


dominan yang berpengaruh terhadap kejadian PJK dengan OR $=4.500$. Rekomendasi dari penelitian ini adalah perlu dilakukan penelitian lanjutan dengan jumlah sampel yang lebih besar dan mengembangkan variabel-varabel yang akan diteliti dikaitkan dengan perilaku lain dan gaya hidup yang mempengaruhi terjadinya PJK.

Kata Kunci : Faktor Risiko, PJK

\section{PENDAHULUAN}

Perubahan gaya hidup

masyarakat Indonesia menyebabkan banyak faktor risiko yang dapat menyebabkan penyakit-penyakit jantung, salah satunya Penyakit Jantung Koroner (PJK). Penyempitan pembuluh darah terjadi karena proses aterosklerosis atau spasme atau kombinasi keduanya. Aterosklerosis yang terjadi karena timbunan kolesterol dan jaringan ikat pada dinding pembuluh darah secara perlahan-lahan, hal ini sering ditandai dengan keluhan nyeri pada dada (Sylvia A. Price, 2006). Menurut Arif Muttaqin (2009), faktor risiko terjadinya PJK dibagi menjadi dua, yaitu faktor yang tidak dapat diubah dan faktor dapat diubah. Faktor yang tidak dapat diubah meliputi usia, riwayat keluarga, dan jenis kelamin. Sedangkan faktor yang dapat diubah meliputi peningkatan lipid serum (hiperlipidemia), tip kepribadian, merokok, gangguan toleransi glukosa (diabetes melitus), gaya hidup kurang aktivitas (inaktivitas fisik), stress psikologis, dan hipertensi.

Penyakit jantung merupakan penyebab kematian nomor satu di dunia. Pada tahun 2005 sedikitnya 17,5 juta atau setara dengan 30,0 \% kematian di seluruh dunia disebabkan oleh penyakit jantung. Menurut Badan Kesehatan Dunia (WHO), $60 \%$ dari seluruh penyebab kematian penyakit jantung adalah PJK (WHO, 2001). Di Indonesia, penyakit jantung juga cenderung meningkat sebagai penyebab kematian. Berdasarkan hasil Survey Kesehatan Rumah Tangga (SKRT) tahun 2010, persentase penderita miokard infark (MI) dengan usia di bawah 40 tahun adalah 2-8\% dari seluruh penderita dan sekitar $10 \%$ pada penderita dengan usia di bawah 46 tahun. Berdasarkan data rekam medis Pusat Jantung Nasional Harapan Kita (PJNHK), penderita MI yang berusia di bawah 45 tahun sejumlah 92 orang dari 962 penderita MI di tahun 2006, atau 10,1\%. Di tahun 2007 angka ini menjadi 10,7\% (117 penderita MI usia muda dari 1096 seluruh penderita MI). Sedangkan di tahun 2008 menjadi 10,1\% (108 penderita MI usia muda dari 1.065 seluruh penderita MI). Sedangkan data yang diperoleh di Surakarta oleh RSUD Dr. Moewardi Surakarta dimana data diperoleh dari hasil rekam medis diperoleh jumlah penyakit jantung koroner khususnya dengan miokard infark diperoleh data pada tahun 2007 sebanyak 155 orang, di tahun 2008 sebanyak 125 orang, dan di tahun 2009 sebanyak 160 orang. Studi pendahuluan dilakukan pada tanggal sampai 11 Februari 2012, didapatkan data angka kejadian PJK sebanyak 10 pasien, dengan jumlah laki-laki 7 orang dan perempuan 3 orang. Pasien perokok sejumlah 7 orang dari 10 pasien, diabetes melitus 4 orang dari 10 pasien, dan hipertensi 6 orang dari 10 pasien. 
Berdasarkan latar belakang dan identifikasi masalah dengan meningkatnya angka kejadian PJK, maka dapat dirumuskan " Apakah faktor risiko yang berpengaruh terhadap prevalensi penyakit jantung koroner?"

\section{METODE PENELITIAN}

Penelitian ini

observasional analitis pendekatan epidemologis dengan desain penelitian cross sectional untuk mempelajari dinamika korelasi antara faktor risiko dengan cara pendekatan, observasi atau pengumpulan data sekaligus pada suatu waktu. Jumlah sampel yang diperoleh sejumlah 40 responden. Kriteria inklusi pada penelitian ini adalah : pasien PJK dan non PJK yang dirawat di ruang ICVCU yang mempunyai hasil diagnosis, elektrokardiografi, dan laboratorium., pasien dengan kesadaran composmentis, pasien yang mampu berkomunikasi dengan baik, serta kooperatif, pasien yang bersedia menjadi responden penelitian dan menandatangani lembar persetujuan. Kriteria eksklusi pada penelitian ini adalah : pasien atau keluarga menolak untuk berpartisipasi dalam pengambilan data penelitian, pasien yang tidak dilakukan pemeriksaan laboratorium, meliputi gula darah dan kadar kolesterol.

Alat pengumpul data yang dipergunakan yaitu instrument yang berupa kuisioner berisi pertanyaan yang mempengaruhi kejadian PJK baik yang dapat diubah maupun yang tidak dapat diubah.

Analisis yang digunakan adalah analisis univariat untuk mendeskripsikan distribusi dari masingmasing variabel yang diteliti. Data disajikan dengan menggunakan tabel serta diinterpretasikan.

Analisis bivariat uji Chi X2 yang digunakan untuk menguji hipotesis pengaruh yang signifikan antara faktor risiko terhadap kejadian PJK. Data ditampilkan dalam bentuk tabel silang yang mengkaitkan antara variabel independen dengan variabel dependen.

Analisis multivariat digunakan untuk mengetahui pengaruh secara bersama-sama variabel independen dan dependen, dan variabel independen mana yang paling besar pengaruhnya terhadap variabel dependen dengan menggunakan uji regresi logistik.

\section{HASIL PENELITIAN \\ Analisis Univariat}

Tabel 1

\section{Distribusi Responden Berdasarkan Karakteristik $(n=40)$}

\begin{tabular}{lcc}
\hline \multicolumn{1}{c}{ Faktor risiko } & Frekuensi & Prosentase \\
\hline Jenis Kelamin & & \\
Perempuan & 14 & 35 \\
Laki-laki & 26 & 65 \\
Usia & & \\
$<40$ tahun & 10 & 25 \\
$>40$ tahun & 30 & 75 \\
\hline
\end{tabular}

Pada tabel 1 menunjukkan jumlah responden yang terbanyak adalah jenis kelamin laki-laki sejumlah 26 responden $(65 \%)$ dan responden yang berusia $>40$ tahun adalah 30 responden $(75 \%)$, 
Tabel 2

Distribusi Responden Berdasarkan Faktor Risiko Terjadinya PJK $(n=40)$

\begin{tabular}{|c|c|c|}
\hline Faktor risiko & Jumlah & $\%$ \\
\hline \multicolumn{3}{|l|}{ Lipidemia } \\
\hline Normal & 17 & 42.5 \\
\hline \multicolumn{2}{|l|}{$\mathrm{a}$} & 57.5 \\
\hline \multicolumn{3}{|l|}{ Tekanan } \\
\hline darah & 12 & 30 \\
\hline Normal & 28 & 70 \\
\hline \multicolumn{3}{|l|}{ Hipertensi } \\
\hline \multicolumn{3}{|l|}{$\begin{array}{l}\text { Kebiasaan } \\
\text { merokok }\end{array}$} \\
\hline Tidak & 9 & 22.5 \\
\hline Merokok & 31 & 77.5 \\
\hline \multicolumn{3}{|l|}{ Gula darah } \\
\hline Normal & 27 & 67.5 \\
\hline Diabetes & 13 & 32.5 \\
\hline \multicolumn{3}{|l|}{ Pola aktivitas } \\
\hline Aktivitas & 9 & 22.5 \\
\hline fisik & 31 & 77.5 \\
\hline \multicolumn{3}{|l|}{ Inaktifitas } \\
\hline \multicolumn{3}{|l|}{$\begin{array}{l}\text { Status } \\
\text { menopause }\end{array}$} \\
\hline Sudah & 2 & 15.4 \\
\hline Belum & 11 & 84.6 \\
\hline \multicolumn{3}{|l|}{ Stress } \\
\hline \multicolumn{3}{|l|}{ kepribadian } \\
\hline Tidak & 12 & 30 \\
\hline Ya & 28 & 70 \\
\hline \multicolumn{3}{|l|}{ Diagnosis } \\
\hline PJK & 30 & 75 \\
\hline PJK & 10 & 25 \\
\hline \multicolumn{3}{|l|}{ Bukan PJK } \\
\hline \multicolumn{3}{|l|}{ Riwayat } \\
\hline keluarga & 10 & 25 \\
\hline Ada & 30 & 75 \\
\hline Tidak & & \\
\hline
\end{tabular}

Pada tabel 2 menunjukkan analisis faktor yang berpengaruh terhadap kejadian PJK adalah hiperlipidemia 23 respon $(57.5 \%)$, mempunyai hipertensi 28 responden (70\%), Gula darah normal 29 responden $(67.5 \%)$, inaktivitas fisik 31 responden $(77.5 \%)$, wanita yang sudah menopause 11 responden (84.6), stress kepribadian 28 responden (70\%), tidak ada riwayat keluarga 30 responden (75\%) dan diagnosis PJK 30 responden (75\%).

\section{Analisis Bivariat}

Tabel 3

Pengaruh Faktor Risiko terhadap Kejadian PJK

\begin{tabular}{|c|c|c|c|c|c|c|c|c|}
\hline \multirow[t]{2}{*}{$\begin{array}{c}\text { Faktor } \\
\text { risiko }\end{array}$} & \multicolumn{2}{|c|}{$\begin{array}{c}\text { Kasus } \\
\text { PJK }\end{array}$} & \multicolumn{2}{|c|}{$\begin{array}{l}\text { Tidak } \\
\text { PJK }\end{array}$} & \multicolumn{2}{|c|}{ Total } & \multirow[t]{2}{*}{$\begin{array}{l}\mathbf{O} \\
\mathbf{R}\end{array}$} & \multirow{2}{*}{$\begin{array}{c}\text { p } \\
\text { val } \\
\text { ue }\end{array}$} \\
\hline & $\mathbf{N}$ & $\%$ & $\mathbf{n}$ & $\%$ & $\mathbf{n}$ & $\%$ & & \\
\hline Jenis & & & & & & & & \\
\hline Kelami & 1 & 7 & 4 & 2 & 1 & 10 & 1.3 & 0.70 \\
\hline $\mathrm{n}$ & 0 & 2 & 6 & 8 & 4 & 0 & & \\
\hline Peremp & 2 & 7 & & 2 & 2 & 10 & & \\
\hline uan & 0 & 7 & & 3 & 6 & 0 & & \\
\hline $\begin{array}{l}\text { Laki- } \\
\text { laki }\end{array}$ & & & & & & & & \\
\hline Usia & & & & & & & & \\
\hline$<40$ & 5 & 5 & 5 & 5 & 1 & 10 & 5.0 & 0.04 \\
\hline tahun & 2 & 0 & 5 & 0 & 0 & 0 & & \\
\hline$>40$ & 5 & 8 & & 2 & 3 & 10 & & \\
\hline tahun & & 3 & & 7 & 0 & 0 & & \\
\hline Lipide & & & & & & & & \\
\hline mia & 1 & 6 & 6 & 3 & 1 & 10 & 2.6 & 0.20 \\
\hline Normal & 1 & 5 & 4 & 5 & 7 & 0 & & \\
\hline Hiperli & 1 & 8 & & 2 & 2 & 10 & & \\
\hline $\begin{array}{l}\text { pidemi } \\
\text { a }\end{array}$ & 9 & 3 & & 7 & 3 & 0 & & \\
\hline Tekana & & & & & & & & \\
\hline $\mathrm{n}$ darah & 7 & 5 & 5 & 4 & 1 & 10 & 3.2 & 0.12 \\
\hline Normal & 2 & 8 & 5 & 2 & 2 & 0 & & \\
\hline Hiperte & 3 & 8 & & 1 & 2 & 10 & & \\
\hline nsi & & 2 & & 8 & 8 & 0 & & \\
\hline $\begin{array}{l}\text { Kebias } \\
\text { aan }\end{array}$ & & & & & & 10 & & \\
\hline meroko & 4 & 4 & 5 & 5 & 9 & 0 & 6.5 & 0.02 \\
\hline $\mathrm{k}$ & 2 & 4 & 5 & 6 & 3 & 10 & & \\
\hline Tidak & 6 & 8 & & 1 & 1 & 0 & & \\
\hline Merok & & 4 & & 6 & & & & \\
\hline
\end{tabular}

ok

Gula

$\begin{array}{lllllllll}\text { darah } & 7 & 5 & 7 & 5 & 1 & 10 & 1.1 & 0.80\end{array}$

Normal $2 \quad 0 \quad 3 \quad 00440$

$\begin{array}{llllll}\text { Diabete } & 3 & 8 & 1 & 2 & 10\end{array}$

$\begin{array}{lllll}\mathrm{s} & 8 & 2 & 6 & 0\end{array}$

Pola

$\begin{array}{lllllllll}\text { aktivita } & 5 & 5 & 4 & 4 & 9 & 10 & 3.3 & 0.14\end{array}$ $\begin{array}{lllllll}\text { s } & 2 & 6 & 6 & 4 & 3 & 0\end{array}$

$\begin{array}{llllll}\text { Aktivit } & 5 & 8 & 1 & 1 & 10\end{array}$

$\begin{array}{llll}\text { as fisik } & 1 & 9 & 0\end{array}$ 


\begin{tabular}{llllllll}
$\begin{array}{l}\text { tas fisik } \\
\text { Stress } \\
\text { kepriba }\end{array}$ & & & & & & & \\
dian & 8 & 6 & 4 & 3 & 1 & 10 & 1.8 \\
Tidak & 2 & 7 & 6 & 3 & 2 & 0 & \\
Ya & 2 & 7 & & 2 & 2 & 10 & \\
& & 9 & & 1 & 8 & 0 & \\
Riwaya & & & & & & & \\
t & & & & & & 10 & \\
keluarg & 8 & 8 & 2 & 2 & 1 & 0 & 1.4 \\
a & 2 & 0 & 8 & 0 & 0 & 10 & \\
Ada & 2 & 7 & & 2 & 3 & 0 & \\
Tidak & & 3 & & 7 & 0 & & \\
\hline
\end{tabular}

Terdapat pengaruh yang bermakna antara usia, ( $p$ value 0.04 ), hiperlipidemia ( $\mathrm{p}$ value 0.20), hipertensi ( $\mathrm{p}$ value 0.12 ), merokok ( $\mathrm{p}$ value 0.02) dan inaktivitas fisik ( $\mathrm{p}$ value 0.14) terhadap kejadian PJK.

\section{Analisis Multivariat}

Tabel 4

Pengaruh Faktor Risiko terhadap Kejadian PJK

\begin{tabular}{|c|c|c|c|c|}
\hline Variabel & B & p Wald & OR & CI 95\% \\
\hline Usia & 0.399 & 0.113 & 1.490 & $\begin{array}{l}0.145- \\
15.294\end{array}$ \\
\hline Hiperlipidemia & 1.228 & 1.957 & 3.414 & $\begin{array}{l}0.611- \\
19.071\end{array}$ \\
\hline Hipertensi & 0.861 & 0.821 & 2.365 & $\begin{array}{l}0.367- \\
15.228\end{array}$ \\
\hline Merokok & 1.504 & 2.052 & $\begin{array}{l}4.500 \\
*\end{array}$ & $\begin{array}{l}0.573- \\
35.359\end{array}$ \\
\hline Inaktifitas fisik & 0.696 & 0.385 & 2.005 & $\begin{array}{l}0.223- \\
18.055 \\
\end{array}$ \\
\hline
\end{tabular}

Tabel 4 menunjukkan bahwa merokok merupakan faktor yang paling dominan dalam mempengaruhi kejadian PJK.

\section{PEMBAHASAN}

Usia lebih dari 40 tahun memiliki risiko lebih besar mengalami PJK. Ada kesesuaian antara hasil penelitian dengan teori AHA (2007) bahwa kerentanan terhadap aterosklerosis koroner meningkat dengan bertambahnya usia. Penyakit yang serius jarang terjadi sebelum usia 40 tahun. Akan tetapi, hubungan antara usia dan timbulnya penyakit mungkin hanya mencerminkan paparan yang lebih panjang terhadap faktor-faktor anterogenik.

Faktor jenis kelamin menunjukkan laki-laki lebih berisiko menderita PJK. Menurut AHA (2007), laki-laki memiliki risiko lebih besar terkena serangan jantung dan kejadiannya lebih awal dari pada wanita. Morbiditas penyakit PJK pada laki-laki dua kali lebih besar dibandingkan dengan wanita dan kondisi ini terjadi hampir 10 tahun lebih dini pada laki-laki daripada perempuan. Wanita relatif kebal terhadap penyakit ini sampai mengalami fase menopause, setelah itu menjadi sama rentannya seperti pria. Hormon esterogen dianggap sebagai pelindung imunitas wanita pada usia sebelum menopause.

Faktor riwayat keluarga menunjukkan yang memiliki riwayat keluarga penyakit jantung tidak berisiko menderita PJK. Menurut Price (2006), riwayat keluarga dapat pula mencerminkan gaya hidup yang menimbulkan stres atau obesitas. Riwayat penyakit jantung koroner (PJK) pada keluarga (MI pada ayah atau saudara laki-laki sebelum berusia 55 tahun atau pada ibu atau saudara perempuan sebelum usia 65 tahun merupakan faktor risiko independent untuk terjadinya PJK. Hasil penelitian ini didukung oleh penelitian sebelumnya yang dilakukan Mamat Supriyanto (2008) yang dilakukan di RS. Kariadi Semarang dengan hasil penelitian riwayat keluarga mempunyai risiko 2,1 lebih besar untuk menderita miokard infark.

Faktor hiperlipidemia berisiko menderita PJK. Hal ini ada kesesuaian antara hasil dengan teori, yang disampaikan oleh Price (2006) 
hubungan antara peningkatan kolesterol serum dengan peningkatan terjadinya arterosklerosis sudah jelas. Kadar kolesterol di atas $180 \mathrm{mg} / \mathrm{dl}$, maka risiko penyakit koronaria meningkat juga. Hasil penelitian ini didukung oleh penelitian sebelumnya yang dilakukan J Ismail dkk (2003) bahwa meningkatnya kolesterol mempunyai risiko 1,67 lebih besar untuk menderita miokard infark.

Faktor tekanan darah menunjukkan responden dengan hipertensi berisiko menderita PJK. Hal ini ada kesesuaian antara hasil dengan teori. Menurut Price (2006), tekanan darah tinggi menyebabkan tingginya gradien tekanan yang harus dilawan oleh ventrikel kiri saat memompa darah. Tekanan tinggi yang terus-menerus menyebabkan suplai kebutuhan oksigen jantung meningkat. Peningkatan tekanan darah sistemik meningkatkan resistensi terhadap pemompaan darah dari ventrikel kiri, akibatnya beban jantung bertambah.

Faktor kebiasaan merokok berisiko menderita PJK. Menurut Price (2006), merokok merupakan faktor risiko mayor untuk terjadinya penyakit jantung, termasuk serangan jantung dan stroke, dan juga memiliki hubungan kuat untuk terjadinya PJK sehingga dengan berhenti merokok akan mengurangi risiko terjadinya serangan jantung. Menghirup asap akan meningkatkan kadar CO dalam hemoglobin sehingga oksigen yang disuplai ke jantung menjadi berkurang, jantung bekerja lebih berat untuk menghasilkan energy yang sama besarnya. Kandungan asam nikotinat pada tembakau memicu pelepasan katekolamin yang dapat menyebabkan kontriksi arteri, sehingga aliran darah dan oksigenasi jaringan menjadi terganggu. Merokok juga dapat meningkatkan adhesi trombosit, yang dapat meningkatkan pembentukan trombus. Hasil penelitian ini didukung oleh penelitian sebelumnya yang dilakukan Mamat Supriyanto (2008) yang dilakukan di RS. Kariadi Semarang bahwa kebiasaan merokok mempunyai risiko 2,4 lebih besar untuk menderita miokard infark.

Hiperglikemia berisiko menderita PJK. Hal ini ada kesesuaian antara hasil dengan teori. Menurut Price (2006), penderita diabetes melitus cenderung memiliki prevalensi aterosklerosis lebih tinggi, demikian pula kasus aterosklerosis koroner dini. Diabetes melitus berhubungan dengan perubahan fisikpatologi pada sistem kardiovaskuler. Diantaranya dapat berupa disfungsi endothelial dan gangguan pembuluh darah yang pada akhirnya meningkatkan risiko terjadinya penyakit jantung koroner. Hiperglikemia menyebabkan peningkatan agregasi trombosit yang dapat menyebabkan pembentukan trombus. Hasil penelitian ini didukung oleh penelitian sebelumnya yang dilakukan Mamat Supriyanto (2008) yang dilakukan di RS. Kariadi Semarang bahwa penyakit diabetes mempunyai risiko 4,1 lebih besar untuk menderita miokard infark.

Faktor pola aktivitas fisik menunjukkan responden dengan inaktivitas fisik berisiko menderita PJK. Hal ini sejalan yang disampaikan Huon (2002), pada latihan fisik akan terjadi dua perubahan pada sistem kardiovaskuler, yaitu peningkatan curah jantung dan redistribusi aliran darah dari organ yang kurang aktif ke organ yang aktif. 
Aktivitas aerobik secara teratur menurunkan risiko PJK, meskipun hanya $11 \%$ laki-laki dan $4 \%$ perempuan memenuhi target untuk berolah raga. Disimpulkan juga bahwa olah raga secara teratur akan menurunkan tekanan darah sistolik, menurunkan kadar katekolamin di sirkulasi, menurunkan kadar kolesterol dan lemak darah, meningkatkan kadar HDL lipoprotein, memperbaiki sirkulasi koroner.

Faktor stress dan kepribadian menunjukkan responden dengan peningkatan stress dan memiliki kepribadian tipe A berisiko menderita PJK. Terdapat kesesuaian antara hasil penelitian dengan teori. Menurut Huon (2002), stress baik fisik maupun mental merupakan faktor risiko untuk PJK. Stress merangsang sistem kardiovaskuler dengan dilepasnya catecholamine yang meningkatkan kecepatan denyut jantung dan menimbulkan vasokonstriksi. Stress menghasilkan suatu percepatan dari proses atherosklerosis pada arteri koroner. Perilaku yang rentan terhadap terjadinya penyakit koroner (kepribadian tipe A) antara lain sifat agresif, kompetitif, kasar, sinis, keinginan untuk dipandang,keinginan untuk mencapai sesuatu, gangguan tidur, kemarahan di jalan, dan lainlain. Baik ansietas maupun depresi merupakan prediktor penting bagi PJK. Hasil penelitian menunjukkan adanya pengaruh yang signifikan antara kebiasaan merokok dengan kejadian PJK $(p=0,140)$. Analisa lebih lanjut didapatkan $p=0,153$ dan $\mathrm{OR}=4.500$, yang berarti bahwa merokok merupakan faktor risiko yang paling dominan yang perpengaruh dengan kejadian PJK. Orang yang telah berhasil menghentikan kebiasaan merokok dapat menurunkan risiko PJK sampai $50 \%$ pada tahun pertama. Risiko akan terus menurun selama orang tersebut tetap tidak merokok.

\section{KESIMPULAN DAN SARAN}

Faktor risiko yang berpengaruh dengan kejadian PJK adalah usia, hiperlipidemia, hipertensi, merokok dan inaktivitas. Dalam penelitian ini faktor risiko yang paling dominan adalah merokok dengan $\mathrm{OR}=4.500$.

PJK dapat dicegah dengan menghindari terjadinya hiperlipidemia, hipertensi, kebiasaan merokok, serta inaktivitas fisik. Usaha yang dapat dilakukan masyarakat adalah mengubah gaya hidup yang sehat dengan cara membatasi makanan yang mengandung lemak, garam, berhenti merokok dan berolah raga secara proposional untuk memberikan efek positif terhadap kesehatan badan (jantung khususnya).

Olahraga dianjurkan selama 20 - 30 menit, 3-5 kali dalam seminggu. Olahraga memberikan efek meningkatkan aliran darah dan membantu memecahkan metabolisme lemak dan kolesterol, sehingga dapat menjaga kestabilan berat badan.

Rekomendasi dari penelitian ini adalah perlu dilakukan penelitian lanjutan dengan jumlah sampel yang lebih besar dan mengembangkan variabel-varabel yang akan diteliti dikaitkan dengan perilaku lain dan gaya hidup yang mempengaruhi terjadinya PJK.

DAFTAR RUJUKAN

Arif Muttaqin.2009. Buku Ajar Asuhan Keperawatan Klien dengan Gangguan Sistem Kardiovaskuler dan 
Hematologi. Jakarta : Penerbit Salemba Medika

Arikunto, S. 2006 . Manajemen Penelitian, Jakarta : Rineka Cipta

Corwin E. 2000. Handbook of Pathophysiology. Jakarta : EGC

Huon H. Gray, Keith D. Dawkins, John

M. Morgan, Iain A. Simpson.

2002. Lecture notes cardiology,

Edisi 4. Jakarta : Erlangga Medical Series

Hidayat. 2009. Metode Penelitian Keperawatan dan Teknik Analisis Data. Jakarta: Salemba Medika

Kalim H. 2001. Penyakit Kardiovaskular dari Pediatrik sampai Geriatrik. Jakarta: Balai Penerbit RS Jantung Harapan Kita.

Machsoef, Ircham. 2009. Metodologi Penelitian Bidang Kesehatan, Keperawatan, Kebidanan, Kedokteran. Yogyakarta : Fitramaya
Nursalam, 2003. Konsep dan Penerapan Metodologi Penelitian Keperawatan. Jakarta : Salemba Medika.

Price, Syilvia A. 2006. Patofisiologi : konsep klinis Proses - Proses Penyakit Edisi (Volume 1). Jakarta : EGC

Soekidjo. 2010. Metodologi Penelitian Kesehatan. Jakarta : Rineka Cipta

Sugiyono. 2006. Metode Penelitian Kuantitatif Kualitatif dan R\&D. Bandung: Alfabeta.

Susiana C. Kadar Malondiadehid (MDA) penderita penyakit jantung koroner di RSUP Dr. Sardjito Yogyakarta, Mandala of Health, a Scientific Journal, Vol 2, .2006 (diakses tanggal 26 Januari 2012)

Yusuf , syamsu. 2011. Teori Kepribadian. Bandung: PT Remaja Rosdakarya 